\title{
The value of kikuyu foggage for overwintering dry ewes
}

\author{
J. F. de Villiers ${ }^{\#}$, T. J. Dugmore, W. A. Botha and J. J. Wandrag ${ }^{1}$ \\ KwaZulu-Natal Department of Agriculture and Environmental Affairs, Private Bag X9059 \\ Pietermaritzburg, 3200, South Africa
}

\begin{abstract}
Kikuyu (Pennisetum clandestinum) is a summer growing tropical pasture species well adapted to the Midlands of KwaZulu-Natal. Kikuyu foggage (standing hay) could play an important role in a fodder flow programme to sustain dry ewes during late winter after their lambs have been weaned in mid-winter. The potential of kikuyu foggage to supply in the feed requirements of dry ewes was evaluated over four winter periods. The foggage was obtained by closing off the kikuyu to grazing during either late January or late February. The foggage was grazed for eight weeks, from mid-July to mid-September, using either strip or continuous grazing systems. Closing off date did not significantly influence the chemical composition of the material on offer. The ewes in the different treatments lost between 4.7 and $10.3 \%$ of their initial body weight over the grazing period. In vitro digestible organic matter (IVDOM) of the foggage declined as winter progressed and was positively correlated with the body weight loss of the ewes. Foggage utilization varied between 36.7 and $43.5 \%$, indicating a high proportion of fodder wastage. The body weight loss of the dry ewes during the grazing period suggested that kikuyu foggage in the KwaZulu-Natal Midlands was unable to sustain the body weight of the dry ewe.
\end{abstract}

Keywords: Kikuyu, foggage, standing hay, sheep, continuous grazing, strip grazing

${ }^{1}$ Present address: ARC, Range and Forage Institute, Private Bag X05, Lynn East, 0039

${ }^{\#}$ Corresponding author. E-mail: devilliersj@cedara.kzntl.gov.za

\section{Introduction}

Kikuyu (Pennisetum clandestinum), grown under dryland conditions, is the predominant summer pasture in the KwaZulu-Natal Midlands (Heard et al., 1984), as well as in many other parts of the province and South Africa. Apart from its suitability as summer grazing, it can be used as foggage (standing hay) during the winter period of May to mid-August (Barnes \& Dempsey, 1993). Cross (1979) found that the crude protein (CP) concentration of kikuyu foggage varied between 118 and $147 \mathrm{~g} / \mathrm{kg}$ dry matter (DM) during the period, late-May to mid-June. Therefore, kikuyu foggage could play an important role in a fodder flow programme to maintain dry ewes during the winter in a system where their lambs were weaned onto green pastures. However, conflicting results on the performance of sheep grazing kikuyu foggage have been reported by Rethman \& Gouws (1973) and Barnes \& Dempsey (1993). The objective of this study was to determine the potential of kikuyu foggage to maintain dry South African Mutton Merino (SAMM) ewes in winter when the grazing of the kikuyu was stopped in different months of summer, and when utilized using two different grazing systems.

\section{Materials and Methods}

The trial was conducted at Cedara $\left(29^{\circ} 32^{\prime} \mathrm{S} ; 30^{\circ} 17^{\prime} \mathrm{E}\right.$; altitude $\left.1067 \mathrm{~m}\right)$ in the KwaZulu-Natal Mistbelt on 1.1 ha of well-established dryland kikuyu pasture grown on a Hutton/Doveton soil form. The annual rainfall is $885 \pm 142 \mathrm{~mm}$, falling predominantly during summer. The foggage was obtained during four seasons by closing off the kikuyu to grazing either in late January or late February. The foggage was grazed using either strip or continuous grazing systems. Data relating to oesophageal and hand-cut samples only pertains to the last two seasons of the trial.

During the growing season the kikuyu was fertilized at $250 \mathrm{~kg}$ nitrogen $(\mathrm{N}) / \mathrm{ha}$ divided into three applications, which is sufficient for the production of $10 \mathrm{t}$ of DM/ha (Manson et al., 1993). The last application took place at each of the closing off dates. The kikuyu was intensively grazed and/or mowed prior to closing off. Frost occurred before the start of each grazing period. Grazing commenced mid-July and continued for eight weeks, until mid-September. Strip grazing was achieved by dividing the grazing area into eight strips using electric fencing. Ewes were moved weekly to a new grazing strip. Ewes in the continuous grazing system were allowed to graze the whole area allocated to them for the entire experimental period.

At the start of each season the quantity of dry material in each treatment was estimated by means of 10 calibrated pasture disc meter readings. The number of ewes allocated per treatment was dependent on the 
dry material available, and, therefore, varied between treatments and seasons. In all the treatments the ewes were allocated $2.6 \mathrm{~kg}$ DM of kikuyu foggage per day, which allowed them twice the DM requirement for maintenance of a $70 \mathrm{~kg}$ ewe (NRC, 1985).

Pasture disc meter (Bransby \& Tainton, 1977) readings (100 per treatment), expressed in cm of disc height, were taken at the beginning and end of each grazing period to estimate the foggage availability and utilization. The following equation, derived under local conditions, was used to estimate kikuyu foggage DM yield: $\mathrm{y}=2573.5+291.185 \mathrm{~d}(\mathrm{P}<0.001$, correlation coefficient $=0.6, \mathrm{n}=200)$ where $\mathrm{y}=$ yield in $\mathrm{kg} \mathrm{DM} / \mathrm{ha}$ and $\mathrm{d}=$ mean pasture disc meter height $(\mathrm{cm})$ (Bartholomew, 1985).

A total of 245 dry SAMM ewes were used over four winters in the experiment. The ewes were weighed weekly. Water and feed were not withheld prior to weighing. The ewes were condition scored (AAC, 1990) at the beginning and end of each grazing period. The average initial body weights and condition scores (scale $=1$ to 5 ) of the ewes at the start of the trial were $63.9 \pm 0.41 \mathrm{~kg}$ and 4 respectively. Fresh water and a mineral supplement (50\% salt, $25 \%$ bone meal and $25 \%$ feed lime) were available to the ewes at all times.

Oesophageal and hand-cut samples were collected only during the last two seasons of the trial. Three mature oesophageal fistulated SAMM wethers were used per treatment to collect samples. The wethers were randomly allocated to the two treatments every week and samples were collected weekly from the relevant strip prior to grazing. Three hand-cut samples per strip, cut at approximately $5 \mathrm{~cm}$ above ground level, were collected. Sufficient material was usually collected within 30 minutes of introducing the fistulated wethers to the foggage. The samples were kept separately and squeezed through two layers of cheesecloth prior to drying overnight, together with the hand-cut samples, at $100{ }^{\circ} \mathrm{C}$ in a forced draft oven. Dried samples were milled through a $1 \mathrm{~mm}$ screen for laboratory analysis. No hand-cut or oesophageally herbage samples were collected from the continuous grazing treatment.

Crude protein (macro-kjeldahl $\mathrm{N} \times 6.25$ ), DM and ash were determined by standard procedures (AOAC, 1980). Acid detergent fibre (ADF) and neutral detergent fibre (NDF) were determined as described by Goering \& Van Soest (1970) and modified as suggested by Van Soest \& Robertson (1980). In vitro digestible organic matter (IVDOM) was determined by the procedure described by Tilley \& Terry (1963) and modified by Minson \& McLeod (1972).

A $2 \times 2$ factorial design, two closing off dates and two grazing systems, were used in this experiment. The experiment was repeated over four years, with re-randomisation of paddocks to the two closing off dates. The continuous and strip grazing were carried out on the same area during the different years. Different ewes were allocated to the treatments every season. Analyses of variance were performed (Statgraphics, 1988) on the chemical composition and animal performance data to test for treatment differences. Herbage samples collected from the strip grazing treatment were used in the regression analysis. Multiple regression (Statgraphics, 1988) techniques were used to describe the relationships between CP, NDF and ADF of hand-cut and oesophageal selected samples over two seasons and body weight changes of ewes of the same seasons. Regression equations were also fitted to describe the relationship between IVDOM of the combined values of the January and February oesophageal and hand-cut foggage samples and week of grazing. Regression analyses were performed using the GENSTAT 5 statistical program (1993) to test relationships between IVDOM of oesophageal selected and hand-cut samples and animal performance.

\section{Results and Discussion}

No significant difference occurred in the average chemical composition of the foggage between the closing off dates (Table 1). It was suggested by Barnes \& Dempsey (1993) that foggage produced with short rest periods will be of higher quality than that produced with longer rest periods. However, the difference in nutritive value is likely to be small, and the amount of forage could be negatively affected by shorter rest periods.

The ability of the grazing animal to select material of higher quality than hand-cut samples of the same pasture has been well documented (Engels \& Malan, 1973). For both closing off dates the foggage selected by the fistulated wethers showed a higher $(\mathrm{P}<0.05) \mathrm{CP}$ concentration than the hand-cut samples (Table 1). The average CP values observed in this study varied from $98.4 \pm 4.7$ to $102.6 \pm 4.8 \mathrm{~g} / \mathrm{kg} \mathrm{DM}$ for selected and $74.5 \pm 2.7$ to $75.5 \pm 2.0 \mathrm{~g} / \mathrm{kg} \mathrm{DM}$ for hand-cut samples. For the first seven weeks on the foggage the oesophageally fistulated wethers were able to select a diet with a CP concentration theoretically sufficient to maintain live mass of a $70 \mathrm{~kg}$ ewe (NRC, 1985) (Figure 1). Barnes \& Dempsey (1993) found that at the start of grazing in late May, sheep grazing kikuyu foggage could evidently select a diet of relatively high quality. During mid-August when animals were removed from the paddocks, the quality of the selected herbage was at or below that required for maintenance of body weight. Dugmore et al. (1991) reported that the protein concentrations in the fistula-selected samples of steers grazing kikuyu were higher than the mean 
of the available herbage at low levels of herbage protein. In contrast, at high levels of herbage CP (> 140 $\mathrm{g} / \mathrm{kg} \mathrm{DM}$ ), the protein concentrations of the selected samples were lower than the mean of the herbage available. Cross (1979) observed CP concentrations that varied from 118 to $145 \mathrm{~g} / \mathrm{kg}$ DM for foggage samples collected from late-May to mid-June. Barnes \& Dempsey (1993) noted mean IVDOM and CP concentrations of 513 and $82 \mathrm{~g} / \mathrm{kg}$ DM respectively in oesophageal kikuyu foggage samples collected by sheep during the period May to August.

Table 1 Average chemical composition (dry matter basis) of the kikuyu foggage in hand-cut and oesophageal selected samples from mid-July to mid-September over two seasons

\begin{tabular}{cccccc}
\hline & & \multicolumn{4}{c}{ Chemical composition (g/kg DM) } \\
& CP & Ash & ADF & NDF & IVDOM \\
\hline Hand-cut samples: & & & & & \\
January closing & $74.5^{\mathrm{a}}$ & 58.5 & 394.7 & $821.1^{\mathrm{a}}$ & 539 \\
& \pm 2.69 & \pm 2.15 & \pm 4.00 & \pm 6.82 & \pm 18.40 \\
& & & & \\
February closing & $75.5^{\mathrm{a}}$ & 58.3 & 390.2 & $817.4^{\mathrm{a}}$ & 530 \\
& \pm 2.02 & \pm 2.29 & \pm 4.48 & \pm 4.68 & \pm 18.40 \\
& & & & \\
Oesophageal selected samples: & & & & 562 \\
January closing & $98.4^{\mathrm{b}}$ & 54.9 & 393.0 & $861.6^{\mathrm{b}}$ & \pm 15.94 \\
& \pm 4.70 & \pm 1.94 & \pm 5.18 & \pm 5.08 & \\
February closing & & & & & \\
& $102.6^{\mathrm{b}}$ & 51.7 & 391.9 & $870.7^{\mathrm{b}}$ & \pm 55 \\
& \pm 4.75 & \pm 1.47 & \pm 5.09 & \pm 4.74 & \pm 14.68 \\
\hline
\end{tabular}

$\overline{\mathrm{a}, \mathrm{b}}$ Values in the same column with different superscripts are significantly $(\mathrm{P}<0.05)$ different $\mathrm{CP}$ - crude protein; ADF - acid detergent fibre; NDF - neutral detergent fibre; IVDOM - in vitro digestible organic matter

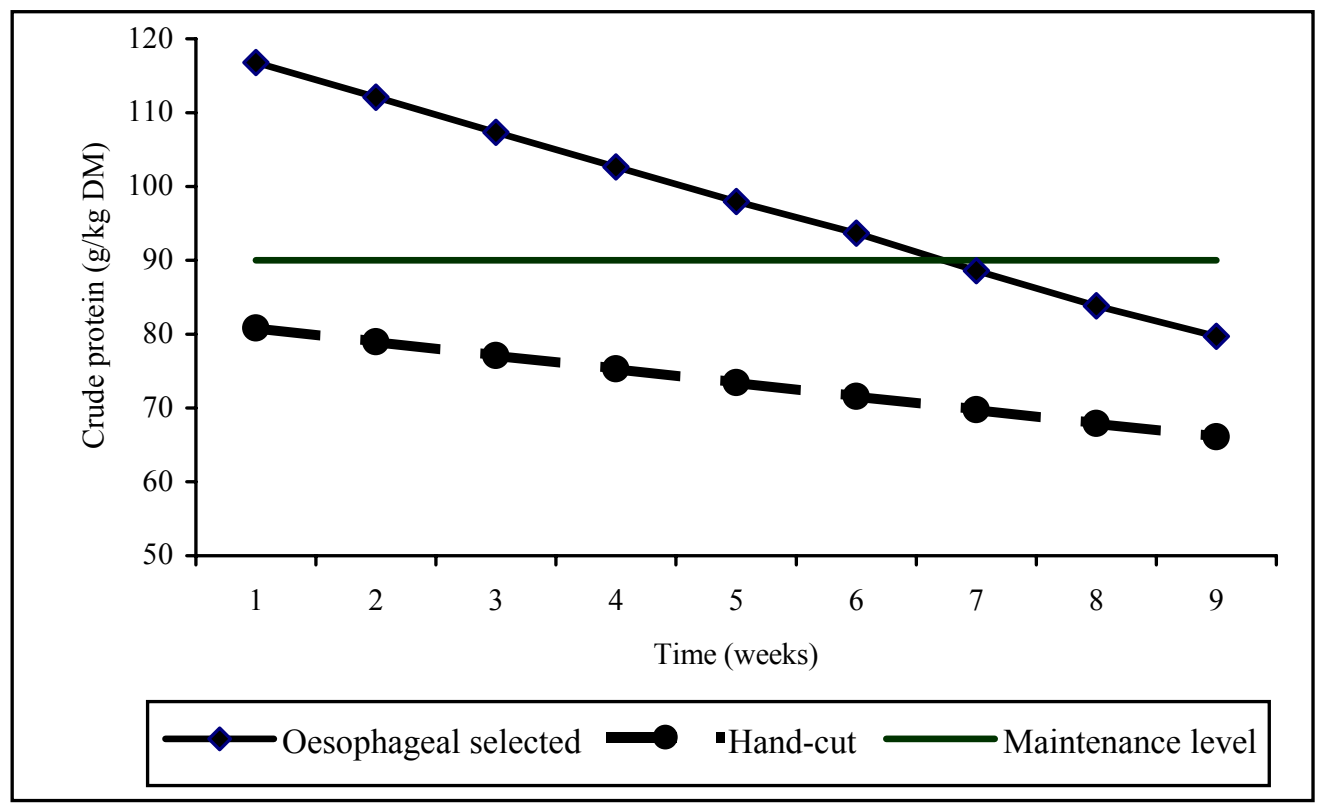

Figure 1 Regression equations illustrating the decline of crude protein concentration of kikuyu foggage in hand-cut samples $\left(\mathrm{y}=82.67( \pm 3.14)-1.844( \pm 0.622) \mathrm{x} ; \mathrm{r}^{2}=0.061 ; \mathrm{S}_{\mathrm{y} . \mathrm{x}}=29.56 ; \mathrm{P}=0.004\right)$ and as selected by oesophageal fistulated wethers $\left(\mathrm{y}=121.47( \pm 6.54)-4.70( \pm 1.3) \mathrm{x} ; \mathrm{r}^{2}=0.122 ; \mathrm{S}_{\mathrm{y} . \mathrm{x}}=86.26 ; \mathrm{P}=0.001\right)$

The high fibre concentration of the kikuyu foggage is not unexpected, considering that the herbage was four to six months old, frosted and weathered during the winter (Table 1). Whitney (1974) recorded an 
ADF concentration of $386 \mathrm{~g} / \mathrm{kg}$ DM for 10-week old kikuyu and Mann (2000) reported an ADF of $391 \mathrm{~g} / \mathrm{kg}$ DM for "stemmy" kikuyu. The average NDF concentration in this study was $819 \pm 4.1 \mathrm{~g} / \mathrm{kg}$ DM for hand-cut samples and $866 \pm 3.5 \mathrm{~g} / \mathrm{kg} \mathrm{DM}$ for oesophageal samples. Compared to the hand-cut samples, animals selected material higher $(\mathrm{P}<0.05)$ in NDF concentration (Table 1). Brand et al. (1999) reported NDF values for hand-cut kikuyu samples ranging from 800 to $930 \mathrm{~g} / \mathrm{kg}$ DM. Maritz et al. (2001) recorded NDF concentrations for kikuyu foggage ranging from 688 to $784 \mathrm{~g} / \mathrm{kg} \mathrm{DM}$ and found that the NDF concentration in the foggage leaves was higher than in the stems. This could explain the higher NDF concentration in the selected material than in the hand-cut samples in the present study. Pattinson (1981) observed that fistulated animals on kikuyu selected against herbage with a high CP concentration and preferred herbage with a relatively high level of ADF. Dugmore et al. (1986) found a positive correlation between the fibre fraction in kikuyu and its digestible organic matter content. The DM disappearance of herbage samples, collected by oesophageal fistula, from nylon bags in the rumen was found to increase with increasing fibre concentration (Pattinson, 1981). Dugmore et al. (1991) found a similar trend where steers selected for higher ADF concentration than the average available in kikuyu pasture. The preceding discussion refers to growing kikuyu. A poorer quality would be expected in kikuyu foggage. Unfortunately, a dearth of information exists on the nutritive value of kikuyu foggage (Reeves, 1997; Marais, 2001).

Linear regression equations describing the relationships between $\mathrm{CP}, \mathrm{NDF}$ and $\mathrm{ADF}$ and body weight change of ewes are summarized in Table 2.

Table 2 The relationship between body weight changes (y) in g/day of the ewes over two seasons and chemical composition ( $\mathrm{x}$ ) of kikuyu foggage collected as hand-cut and oesophageal selected samples

\begin{tabular}{|c|c|c|c|c|c|c|}
\hline & & Equation & $\mathrm{n}$ & $r^{2}$ & $\begin{array}{c}\text { Level of } \\
\text { significance }\end{array}$ & $\mathrm{S}_{\mathrm{y} \cdot \mathrm{x}}$ \\
\hline \multirow{3}{*}{$\begin{array}{l}\text { Hand-cut } \\
\text { samples }\end{array}$} & $\mathrm{CP}$ & $y=7.6( \pm 118.1)-7.7( \pm 15.34) x$ & 6 & 0.06 & 0.65 & 40.1 \\
\hline & NDF & $y=-3113( \pm 1647.6)+37.3( \pm 20.09) x$ & 6 & 0.46 & 0.14 & 30.3 \\
\hline & $\mathrm{ADF}$ & $y=576( \pm 299.3)-16.3( \pm 7.76) x$ & 6 & 0.52 & 0.10 & 28.5 \\
\hline \multirow{3}{*}{$\begin{array}{l}\text { Oesophageal } \\
\text { selected samples }\end{array}$} & $\mathrm{CP}$ & $y=169( \pm 55.43)+11.6( \pm 5.32) x$ & 6 & 0.54 & 0.09 & 28.0 \\
\hline & NDF & $y=845( \pm 738.6)-10.4( \pm 8.57) x$ & 6 & 0.27 & 0.29 & 35.3 \\
\hline & $\mathrm{ADF}$ & $y=486( \pm 158.3)-13.7( \pm 4.03) x$ & 6 & 0.74 & 0.03 & 21.0 \\
\hline
\end{tabular}

CP - crude protein; NDF - neutral detergent fibre; ADF - acid detergent fibre

In the oesophageal selected samples the negative correlation between live weight change and ADF concentration was significant $(\mathrm{P}<0.05)$. A similar trend $(\mathrm{P}=0.10)$ was apparent for the hand-cut samples. The NDF values of selected samples, although not significant, indicated that body weight losses will occur when the NDF concentration is above $810 \mathrm{~g} / \mathrm{kg}$ DM. This is a higher concentration than suggested by Meissner et al. (1991) who concluded that the metabolisable energy intake on forages with NDF concentrations exceeding $550 \mathrm{~g} / \mathrm{kg}$ DM may be insufficient to sustain satisfactory animal production. They attributed this to slow fermentation and long ruminal retention times. The question could be asked: What is "satisfactory animal performance", where, in the present study, it was the sustaining of dry ewes to maintain their body weight or have a slight increase in weight? Cowan (2000) considered the high NDF concentrations ( 550 to $800 \mathrm{~g} / \mathrm{kg} \mathrm{DM}$ ) of tropical grasses to be a major factor limiting production.

In this study, no significant differences in IVDOM were found between hand-cut and oesophageal samples during the first week of grazing and over the total grazing period (Table 1). Köster et al. (1992) found no differences in IVDOM between hand-cut and oesophageal samples of bana grass, kikuyu and forage sorghum selected by steers. A possible reason suggested was that the opportunity to select herbage is reduced when steers are presented with a relatively homogeneous sward of a young physiological age compared to a heterogeneous one.

The effects of the grazing system and closing off dates on body weight changes were not consistent from year to year because of the difference in DM yield and stocking densities. Over the four seasons, the ewes in all four treatments lost weight, varying from 4.7 to $10.3 \%$ of the initial body weight during the eightweeks grazing periods (Table 3 ).

The relationship between IVDOM of oesophageal selected and hand-cut samples (y; \% of DM) and week of grazing $(\mathrm{x})$ (mid-July $=1$ to mid-September $=9$ ) were: $\mathrm{y}=63.9-2.21 \mathrm{x}$ for oesophageal selected samples and $\mathrm{y}=63.9-2.83 \mathrm{x}$ for handcut samples $\left(\mathrm{r}^{2}=0.603 ; \mathrm{P}=0.001 ; \mathrm{n}=71\right)$. 
Table 3 Weight changes of dry ewes grazing kikuyu foggage during an eight week period over four seasons

\begin{tabular}{|c|c|c|c|c|c|c|}
\hline \multirow{3}{*}{$\begin{array}{l}\text { Closing off date } \\
\text { Grazing system }\end{array}$} & \multicolumn{4}{|c|}{ Treatment } & \multirow{2}{*}{\multicolumn{2}{|c|}{ LSD }} \\
\hline & \multicolumn{2}{|c|}{ End January } & \multicolumn{2}{|c|}{ End February } & & \\
\hline & Strip & Continuous & Strip & Continuous & $5 \%$ & $1 \%$ \\
\hline \multicolumn{7}{|l|}{$\begin{array}{l}\text { Body weight } \\
\text { change }(\mathrm{kg})\end{array}$} \\
\hline 1989 & -3.41 & -2.23 & -0.64 & 0.25 & 1.89 & 2.51 \\
\hline 1990 & -7.89 & -10.59 & -7.00 & -7.92 & 1.42 & 1.89 \\
\hline 1991 & -2.04 & -1.71 & 0.85 & 1.22 & 2.08 & 2.77 \\
\hline 1992 & -6.21 & -9.15 & -8.42 & -7.13 & 1.97 & 2.62 \\
\hline $\begin{array}{l}\text { Average body } \\
\text { Weight loss (\%) }\end{array}$ & 8.2 & 10.3 & 6.6 & 4.7 & & \\
\hline
\end{tabular}

LSD - least significant difference

The negative relationship $(\mathrm{P}=0.001)$ between IVDOM and week of grazing illustrates the decrease in digestibility of kikuyu foggage as winter progressed. During the last week of grazing the IVDOM of oesophageal samples was higher $(\mathrm{P}<0.01)$ than that of the hand-cut samples. The difference in digestibility of oesophageal and hand-cut samples towards September could be due to the green shoots of early spring growth selected by the animals.

In a regression analysis no significant differences between the slopes or the intercepts of the handcut and selected samples were found. The data of the hand-cut and selected samples for the last two seasons were combined in the regression analysis. The relationship between body weight change (g/day) (y) and $\operatorname{IVDOM}(\mathrm{x} ; \%$ of DM) was:

$$
\begin{aligned}
& 1991: \mathrm{y}=-92.5( \pm 50.1)+1.88( \pm 0.952) \mathrm{x}\left(\mathrm{r}^{2}=0.112 ; \mathrm{P}=0.061 ; \mathrm{n}=24\right) \\
& 1992: \mathrm{y}=-593( \pm 100)+11.76( \pm 2.06) \mathrm{x}\left(\mathrm{r}^{2}=0.547 ; \mathrm{P}=001 ; \mathrm{n}=27\right)
\end{aligned}
$$$$
\text { Both seasons: } \mathrm{y}=-286.2( \pm 58.5)+5.49( \pm 1.16) \times\left(\mathrm{r}^{2}=0.301 ; \mathrm{P}=001 ; \mathrm{n}=51\right)
$$

The regression equations indicated an improvement in body weight with an increase in the IVDOM. The regression equations for both seasons indicated that the ewes started to lose weight when the IVDOM of the foggage dropped below 52.1\%, which occurred at approximately mid-August. The IVDOM of the oesophageal selected samples varied from $60 \%$ in mid-July to $45 \%$ in mid-September and were consistently lower than $50 \%$ after mid-August, possibly explaining the body weight loss after mid-August. Barnes \& Dempsey (1993) reported that in one trial wether lambs were able to maintain body weight and in another that dry ewes and wether lambs lost between 8 and $10 \%$ of their initial weight, irrespective of differences in foggage quality. These authors also noted a rapid loss in condition in livestock kept on foggage that began to shoot during the spring period. Similarly, the ewes in this study experienced a rapid decline in body weight after mid-August, suggesting that grazing after this point should be avoided if possible. If grazing of foggage is still required after mid-August, the inclusion of supplementary feeding should be considered.

The DM yield of the end-January closing-off treatment was $7.85 \pm 0.41 \mathrm{t} / \mathrm{ha}$ and that of the endFebruary treatment $6.53 \pm 0.29 \mathrm{t} / \mathrm{ha}$. This implies that more animals/ha could be carried or a longer grazing period would be possible when closing-off takes place at the end of January compared to the end of February (Table 4). These results are in agreement with those of Barnes \& Dempsey (1993) who found that the quantity of foggage increased with an increase in the length of the rest period during the growing season. With respect to the efficiency of pasture utilization, Rethman \& Gouws (1973) noted that where pastures were 10 to $20 \mathrm{~cm}$ tall at the first frost, the utilization was good. However, when growth was more abundant, wastage was high. The average length of the foggage during the 8-week grazing period is given in Table 4 .

The data of Table 4 indicates that 36.7 to $43.5 \%$ of the foggage was utilized. Barnes \& Dempsey (1993) found that leaf was utilized to a greater extent than stem, and that approximately $51 \%$ of the herbage $\mathrm{DM}$ and $55 \%$ of the in vitro digestible organic matter were utilized. Observations during the four seasons of the trial showed that, in the strip grazing treatments, the ewes consumed all the herbage that had been cut by a mower for placement of the electric fence. Therefore, it appears as if the foggage in our study was not as acceptable to the ewes as the cut material. This could have affected intake adversely. 
Table 4 Disc meter readings, herbage available before and after grazing, and utilization of kikuyu foggage

\begin{tabular}{|c|c|c|c|c|}
\hline \multirow{3}{*}{$\begin{array}{l}\text { Closing off date } \\
\text { Grazing system }\end{array}$} & \multicolumn{4}{|c|}{ Treatment } \\
\hline & \multicolumn{2}{|c|}{ End January } & \multicolumn{2}{|c|}{ End February } \\
\hline & Strip & Continuous & Strip & Continuous \\
\hline \multicolumn{5}{|l|}{ Before grazing: } \\
\hline Disc meter reading $(\mathrm{cm})$ & $19.1 \pm 6.22$ & $17.6 \pm 6.40$ & $16.3 \pm 5.83$ & $17.3 \pm 6.07$ \\
\hline $\mathrm{kg} \mathrm{DM} / \mathrm{ha}^{*}$ & $8131 \pm 1810.3$ & $7712 \pm 1697.9$ & $7316 \pm 1697.9$ & $7607 \pm 1767.5$ \\
\hline \multicolumn{5}{|l|}{ After grazing: } \\
\hline Disc meter reading $(\mathrm{cm})$ & $7.8 \pm 2.47$ & $7.9 \pm 2.94$ & $6.4 \pm 2.22$ & $5.9 \pm 2.32$ \\
\hline $\mathrm{kg} \mathrm{DM} / \mathrm{ha} *$ & $4816 \pm 718.6$ & $4880 \pm 855.6$ & $4449 \pm 647.6$ & $4300 \pm 674.5$ \\
\hline Utilization (\%) & 40.8 & 36.7 & 39.2 & 43.5 \\
\hline
\end{tabular}

\section{Conclusion}

In this study it was found that body weight changes of ewes were not influenced by grazing system or closing off dates. The data suggested that when the IVDOM drops below $52 \%$, the quality of unsupplemented kikuyu foggage in the local environment is insufficient to maintain the body weight of dry ewes. This suggested that kikuyu foggage should probably be grazed before mid-August. The optimal grazing period for kikuyu foggage and the introduction of supplements to optimize kikuyu foggage utilization need further investigation. From this study it is clear that the limitation regarding forage quality and the extent and period of utilization should be considered when kikuyu foggage is utilized for overwintering.

\section{Acknowledgements}

The authors thank C. Stevens for the statistical analyses. J. Marais and P. Bartholomew are thanked for editorial comments and suggestions.

\section{References}

AAC, 1990. Feeding standards for Australian livestock. Ruminants. Australian Agricultural Council, Ruminants Subcommittee. CSIRO publications, Melbourne.

AOAC, 1980. Official methods of analysis (13th ed.). Association of Official Analytical Chemists, Inc., Washington, D.C.

Barnes, D.L. \& Dempsey, C.P., 1993. Grazing trials with sheep on kikuyu (Pennisetum clandestinum Chiov.) foggage in the eastern Transvaal highveld. Afr. J. Range For. Sci. 10, 66-71.

Bartholomew, P.E., 1985. Beef production from kikuyu and Italian ryegrass. PhD thesis, University of Natal, Pietermaritzburg, South Africa.

Brand, T.S., Franck, F. \& Coetzee, J., 1999. Kikuyu (Pennisetum clandestinum) pasture for sheep. 1. Pasture quality and nutrient intake of ewes. N. Z. J. Agric. Res. 42, 459-465.

Bransby, D.I. \& Tainton, N.M., 1977. The disc pasture meter: possible application in grazing management. Proc. Grassld. Soc. S. Afr. 12, 115-118.

Cowan, R.T., 2000. Trends in feeding systems for dairy production in the subtropics of Australia. $38^{\text {th }}$ South African Society of Animal Science Congress, 25 to 27 July 2000, Alpine Heath Conference Village, KwaZulu-Natal, South Africa.

Cross, G.W., 1979. Maintaining the nutritive value of Pennisetum clandestinum for milk production. Proc. Grassld. Soc. S. Afr. 14, 61-63.

Dugmore, T.J., Du Toit, P.C.V. \& Morning, S.J., 1991. Dietary selection by steers grazing kikuyu. S. Afr. J. Anim. Sci. 21, 194-197.

Dugmore, T.J., van Ryssen, J.B.J. \& Stielau, W.J., 1986. Effect of fibre and nitrogen content on the digestibility of Kikuyu (Pennisetum clandestinum). S. Afr. J. Anim. Sci. 16, 197-201.

Engels, E.A.N. \& Malan, A., 1973. Sampling of pastures in nutritive evaluation studies. Agroanimalia. 5, 8994.

Genstat, 1993. Genstat 5 Committee of the Statistical Department, Rothamstead Experimental Station. 
Genstat 5, Release 3 Reference Manual. Oxford, Clarendon Press.

Goering, H.K. \& Van Soest, P.J., 1970. Forage Fibre Analysis. USDA - ARS Agric. handbook. No. 379.

Heard, C.A.H., Tainton, N.M. \& Edwards, P.J., 1984. The contribution of pasture and veld to feeding of dairy and beef herds in Natal Midlands. J. Grassld. Soc. S. Afr. 1, 37-40.

Köster, H.H., Meissner, H.H., Coertze, R.J. \& Rethman, N.F.G., 1992. Voluntary intake and quality of diet selected by cattle grazing bana grass, kikuyu and forage sorghum. S. Afr. J. Anim. Sci. 22, 35-41.

Mann, J., 2000. The digestibility, intake and faecal marker patterns of Hereford and Friesland bulls consuming Kikuyu (Pennisetum clandestinum) using N-alkanes. MSc (Agric) thesis, University of Natal, South Africa.

Manson, A.D., Milborrow, D.J., Miles, N., Farina, M.P.W. \& Johnson, M.A., 1993. Explanation of the Cedara Computerised Fertilizer Advisory Service. Department of Agriculture, Directorate of Technology and Training, Pietermaritzburg, South Africa.

Marais, J.P., 2001. Factors affecting the nutritive value of kikuyu grass (Pennisetum clandestinum) - a review. Trop. Grass1. 35, 65-84.

Maritz, E., van Ryssen, J.B.J. \& O’Donovan, W.M., 2001. Changes in chemical composition of kikuyu foggage as winter progressed. $36^{\text {th }}$ Grassland Society of Southern Africa Congress, 22 to 25 January 2001, Aventura Aldam, South Africa, pp. 44-45.

Meissner, H.H., Köster, H.H., Nieuwoudt, S.H. \& Coertze, R.J., 1991. Effect of energy supplementation on intake and digestion of early and mid-season ryegrass and Panicum / Smuts winter hay, and on in sacco disappearance of various forage species. S. Afr. J. Anim. Sci. 21, 33-42.

Minson, D.J. \& Mcleod, M.N., 1972. The in vitro technique: Its modification for estimating digestibility of large numbers of tropical pasture samples. Division of Tropical Pastures Technical Paper No. 8, Commonwealth Scientific Industrial Organization, Australia.

NRC, 1985. Nutrient Requirements of Sheep (6th ed.). National Academy Press, Washington, D. C.

Pattinson, N.B., 1981. Dry matter intake: an estimation of the animal response to herbage on offer. MSc (Agric) thesis, University of Natal, South Africa.

Reeves, M., 1997. Milk production from kikuyu (Pennisetum clandestinum) grass pasture. PhD thesis, University of Sydney, Australia.

Rethman, N.F.G. \& Gouws, C.I., 1973. Foggage value of kikuyu (Pennisetum clandestinum Hochst. ex Chiov.). Proc. Grassld. Soc. S. Afr. 8, 101-105.

Statgraphics, 1988. Statistical Graphics Corporation, Inc. 14.1.

Tilley, J.M.A. \& Terry, R.A., 1963. A two stage technique for in vitro digestion of forage crops. J. Brit. Grassl. Soc. 18, 104-111.

Van Soest, P.J. \& Robertson, J.B., 1980. Systems of analysis for evaluating fibrous feeds. In: Standardization of analytical methodology for feeds. Eds. Pigden, W.J., Batch, C.C. \& Graham, M. Proceedings of a workshop held in Ottawa, Canada, pp. 49-60.

Whitney, A.S., 1974. Growth of kikuyu grass (Pennisetum clandestinum) under clipping. II. Regrowth characteristics in relation to nitrogen fertilization and climate. Agron. J. 66, 763-767. 